ISSN: 2224-0616

Int. J. Agril. Res. Innov. Tech. 10(1): 71-79, June 2020

DOI: https://doi.org/10.3329/ijarit.v10i1.48096
OPEN 2 ACCESS

Available online at https://ijarit.webs.com https://www.banglajol.info/index.php/IJARIT

\title{
Evaluating the effect of in-situ rainwater harvesting techniques on maize production in moisture stress areas of humbo woreda, wolaita zone, southern Ethiopia
}

\author{
W. Naba 1 , A. Moges ${ }^{2}$ and A. Gebremichael ${ }^{*}$ \\ Received 15April 2020, Revised 23 April 2020, Accepted 20 June 2020, Published online 30 June 2020
}

\section{A B S T R A C T}

The study was conducted to investigate the effect of different in-situ water harvesting structures as soil moisture conservation techniques under maize crop production in Abela Sippa kebele Wolaita zone, Ethiopia where rainfall variation is affecting agriculture with prolonged dry spells during critical crop growth stages. The experiment was laid out in a Randomized Complete Block Design, with three replications and four treatments. The four treatments used in the study were; Control, Targa, Tie-ridge and Zai pits. Findings from this study revealed that maize grain yield and yield components, such as, grain yield, dry matter biomass, and cob length were highly significant $(\mathrm{p}<0.05)$ on Targa. Soil-moisture content over the crop growing season at dry spell periods was significantly higher in Targa and Tie ridges than the control. Maize yield of $\left(7150 \mathrm{~kg} \mathrm{ha}^{-1}\right),\left(6190 \mathrm{~kg} \mathrm{ha}^{-1}\right),\left(4500 \mathrm{~kg} \mathrm{ha}^{-1}\right)$ and (4900 kg ha-1) was obtained from Targa, Tie ridge, Zai pits and Control, respectively. Targa and Tie ridge treatments recorded higher net returns (29712 and $25164 \mathrm{~kg} \mathrm{ha}^{-1}$ ) than Control (20370 kg ha-1) and Zai (14350 kg ha-1) treatments. The results revealed that the in-situ rainwater harvesting techniques could play great role in improving crop yield in dry periods. However, the utilization of the technology is surrounded by various constraints. The major constraints include labour, cost, lack of knowledge and crops planted on bunds. The findings suggest that Targa structure improved water availability during the growing season, thereby protecting crops from dry periods and it needs minimum cost, less labor power , and easily constructed by local farmers (not require complicated knowledge).

Keywords: In-situ Rainwater harvesting, Farmers' perception, Soil moisture, Maize yield.

${ }^{1}$ Southern Agricultural Research Institute, Arba Minch Agricultural Research Center, Arba Minch, Ethiopia.

${ }^{2}$ Hawassa Institute of Technology, Hawassa University, Hawassa, Ethiopia.

${ }^{3}$ Southern Agricultural Research Institute, Bonga Agricultural Research Center, Bonga, Ethiopia.

*Corresponding author's email: gebremichaelaby@gmail.com (A. Gebremichael)

Cite this article as: Naba, W., Moges, A. and Gebremichael, A. 2020. Evaluating the effect of in-situ rainwater harvesting techniques on maize production in moisture stress areas of humbo woreda, wolaita zone, southern Ethiopia. Int. J. Agril. Res. Innov. Tech. 10(1): 71-79. https://doi.org/10.3329/ijarit.v10i1.48096

\section{Introduction}

The efficient use of water in agricultural systems is needed to improve crop production and resilience to environmental adversities that may be caused by climate change and extended droughts, especially in arid and semi-arid areas. Marginal and erratic rainfall aggravated by the loss of water by runoff and evaporation are the main causes of low crop production in these areas (Yosef and Asmamaw, 2015). Ethiopia has been dependent on subsidence rain-fed agriculture for centuries, and crop production has thus been heavily reliant on the availability of rainwater (Araya and Stroosnijder, 2010; Yosef and Asmamaw, 2015).
Out of the 13.6 million ha of cultivated land in Ethiopia, close to $97 \%$ is rain-fed implying that the nation's annual harvests depend heavily on the patterns of the seasonal rains (Awulachew et al., 2005; FAO, 2005). Analysis of maize crop yield patterns since the 1970 s shows that crop yields are mainly dependent on season quality (rainfall quantity and distribution) thereby making rainfall the most important crop yield determinant (MLARR, 2001) crop yield depression and crop failure due to moisture stress is thus a common phenomenon in the semi-arid areas. Studies in Ethiopia have also shown that improved crop productivity can only be achieved in the region if policies and strategies are adopted by regional governments to improve agricultural water management (Mahoo et at., 2007).

International Journal of Agricultural Research Innovation \& Technology An open access article under (c) 
Farmers in the semi-arid zones have therefore developed strategies, including RWH, to cope with this uncertain and erratic rainfall patterns. RWH practices refer to all practices whereby rainwater is collected artificially to make it available for cropping or domestic purposes (Ngigi et al., 2005). Water harvesting techniques (WHTs) have played a key role in improving the efficient use of rainwater and have increased the sustainability and reliability of rain-fed agriculture (Biazin et al., 2012). Rain Water Harvesting (RWH) has been promoted as an approach to integrate land and water management, which could contribute to recovery of agriculture production in rain fed systems and the general water resources (Rockström et al., 2002). In-situ WHTs improve the availability of water in the soil profile to decrease the effects of dry periods caused by the seasonal variation of rainfall. Soils contemporarily hold water, so insitu water harvesting prolongs the availability of water in the root zone by reducing runoff and evaporation losses (Vohland and Barry, 2009). Accordingly, in-situ RWH, using different soil and water conservation (SWC) activities, has gained renewed interest; as part of the world wide effort to combat climate change and currently the scheme is in progress at an even larger scale (Mintesinot and Mitiku, 2002). The study area under consideration, Humbo Woreda, is characterized by, risk of meteorological droughts/rainfall inadequate and poorly distributed over the cropping season to produce acceptable crop yield and erratic occurrence of rainfall with spatial and temporal variability and uncertainty (Ahmed and Naggar, 2003). During the 'Belg' season, the rains are very rare; Farmers usually delay planting until a substantial amount of rainfall has occurred, to avoid the risk of crop failure in early stages of crop growth. Such delay often results in inadequate moisture supplies during the flowering stage of the cereal crops and hence minimum grain yield (Abiye et al., 2002). Therefore, this research was required to fill the gaps to enable the farmers use in-situ water harvesting techniques in order to boost the production of maize crop. Therefore, the objective of the research was to evaluate the contribution of selected in-situ rainwater harvesting techniques for crop production under rain-fed farming in moisture stress areas of Humbo woreda, Wolaita zone.

\section{Materials and Methods}

\section{Description of the study area}

The field experiment was conducted at Humbo woreda which is one of the 12 woreda of Wolaita Zone and it is far from the capital city of Ethiopia $380 \mathrm{~km}$ and $18 \mathrm{~km}$ south of Soddo town on the main road to Arba Minch. The woreda is located 1420 meter above sea level, $6^{\circ} 43^{\prime} 44^{\prime \prime N}$ latitude and $37^{\circ} 45^{\prime} 51^{\prime \prime} \mathrm{E}$ longitude in South Nation Nationalities and People Regional State (SNNPRS) shown in Fig. 1 below.

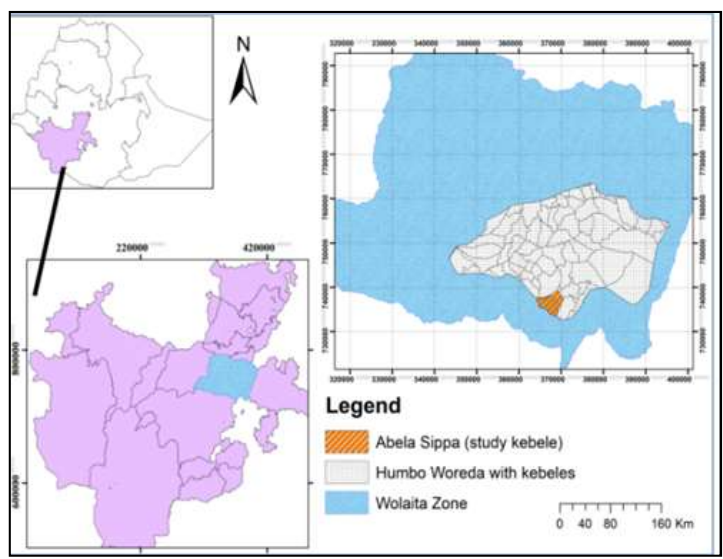

Fig. 1. Map of the study location.

The climatic condition of the study area, average daily temperature is $18.3^{\circ} \mathrm{C}-21.0^{\circ} \mathrm{C}$, the annual rainfall varies between $710 \mathrm{~mm}$ and $1337 \mathrm{~mm}(\mathrm{CV}$ $=16 \%$ ) with a mean of $1148 \mathrm{~mm}$ for the past 11 years. The rainy season can further be divided into 2 periods: the "Belg" or small rains that take place from, February, March and April but high (peak) rainfall on May and low rainfall on June (flowering stage) these indicated that during the 'Belg' season, the rains are very rare and the 'Kiremt' or big rains that take place from July to September (Fig. 2). The erratic and unreliable nature of the rainfall in the woreda affects the rain fed crop production, which is the main economic stay for the dwellers of the area (Fitsum et al., 1999).

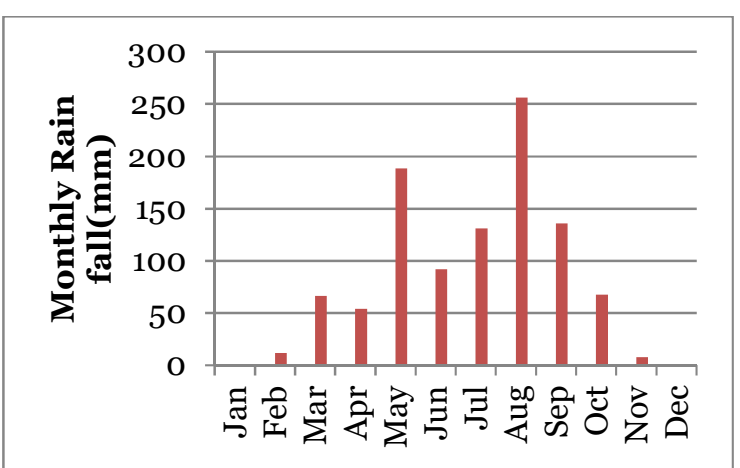

Fig. 2. Average monthly rainfall of the study area.

Soil physical characteristics such as bulk density $\left(1.55 \mathrm{~g} / \mathrm{cm}^{3}\right)$ and soil texture (clay $75 \%$, sand $9 \%$, silt $16 \%$ ) which shows soil type of the area was sandy loam were determined in the laboratory. Woreda is sub divided into 2 urban and 41 rural Kebeles, with total area of 86,646 ha, which is $70 \%$ of lowland and 30\% midland (WZFED, 2005). Mixed agriculture is the main economic activities, which accounts $92 \%$ of the total population in the study area. The major crops 
grown in the study area are cereals such as teff, maize, sorghum, cotton, cowpea and root crops like sweet potatoes, and fruits like mango, avocado and banana according to Humbo District Agricultural Office (HDoA).

\section{Experimental design}

A field experiment was conducted on the effect of different in-situ soil moisture conservation structures for maize production under rain fed farming situations during cropping season of 2018 at Abela Sippa kebele. The experiment consisted of four different in-situ soil moisture conservation techniques (Targa, Zai, Tie ridge and Control) with maize planting at spacing of $40 \mathrm{~cm}$ $\mathrm{x} 75 \mathrm{~cm}$ between plant and between rows. The experiment have a completely randomized block design (RCBD) used because; there is fertility gradient on experimental field.

A layout of completely randomized block design with four treatments and three replicates, for a total of 12 plots. Each plot was $6 \mathrm{~m} \mathrm{x} 10 \mathrm{~m}$ area with slope range of $3-5 \%$. Plots were separated by $0.5 \mathrm{~m}$ to facilitate crop management operations and $1 \mathrm{~m}$ space between blocks.

Based on previous recommendations of fertilizer application on maize by Debelle and Friessen (2001), $100 \mathrm{~kg} \mathrm{ha}^{-1}$ Urea in two applications (50 $\mathrm{kg} \mathrm{ha}^{-1}$ during sowing and another $50 \mathrm{~kg} \mathrm{ha}^{-1}$ was applied 40 days after sowing) and $100 \mathrm{~kg} \mathrm{ha}^{-1}$ of DAP in one application (only during sowing) were applied on the plots. A local maize cultivar (Awassa BH540) was planted with density of 40,000 plants per hectare with spacing of $40 \mathrm{~cm}$ and $75 \mathrm{~cm}$ between plants and between rows, respectively.

Tied ridge: When the ridges or furrows are blocked with earth ties with intervals, they are known as 'tied ridges' or furrow disking. In Tiedridges, the earth ties are spaced at fixed distances to form a series of micro-catchment basins in the field. Tie spacing for tied-ridge was $5 \mathrm{~m}$ interval made by manually with $75 \mathrm{~cm}$ spacing between consecutive ridges constructed along contour line. One plot of tie-ridge was $6 \mathrm{~m} \times 10 \mathrm{~m}$.

Planting pit/Zai: Is pitting cultivation, which takes place in the form of Zai which is dug with distance between pit $40 \mathrm{~cm}$ and between row 75 $\mathrm{cm}$ to a depth of $16 \mathrm{~cm}$. crop residue $\left(4.5 \mathrm{mg} \mathrm{ha}^{-1}\right)$ was incorporated and decomposed in the soil before sowing on the Zai pits to keep the fertility level of the soil at optimum condition and $100 \mathrm{~kg}$ $\mathrm{ha}^{-1}$ DAP and $100 \mathrm{~kg} \mathrm{ha}^{-1}$ urea.

Targa: Is a rectangular basin built from soil or crop residue before rain season constructed along contour lines spaced $1.5 \mathrm{~m}$ apart, which are tied approximately at $1.43 \mathrm{~m}$ interval by ridges made in horizontal 7 and vertical 4 number of Targa with a total 28 Targa constructed in each plot at staggered position across the contour. Within each, the Targa two rows prepared by $75 \mathrm{~cm}$ space with a total of 8 numbers of rows and 24 planting pits in each row. The bund ridges of Targa rise about $0.2 \mathrm{~m}$ above the ground and the embankment thickness $0.2 \mathrm{~m}$.

\section{Methods of data collection}

\section{Determining soil moisture content}

The state of water in the soil can be described in two ways: quantity present and energy status. The quantity present is expressed as gravimetric (mass) or volumetric. The gravimetric water content is the mass of water in a unit mass of dry soil ( $g$ of water/g of dry soil). The wet weight of soil sample is determined; the sample is dried at $105^{\circ} \mathrm{C}$ to constant weight and reweighed (Gardner, 1986). The volumetric water content is expressed in terms of the volume of water per volume of soil $\left(\mathrm{cm}^{3}\right.$ of water $/ \mathrm{cm}^{3}$ of soil). Measuring soil moisture measurements was conducted at three periods (initial, development and mid stage) to evaluate the amount of soil water during just after the rainfall and after 10 days of without rainfall during crop growing seasons.

An auger was used for soil sampling from the depth of $0-20 \mathrm{~cm}$ and $20-40 \mathrm{~cm}$ because $70 \%$ of moisture extraction was taken from the rooting depth $(0.4 \mathrm{~m})$. From each of the two depths collect sub samples of the auger sample and mix well in a plastic bucket. The weight of the wet soil samples was measured and put in an oven at $105^{\circ} \mathrm{C}$ for 24 hours and then the weight of dry samples was measured. The soil water stored (\%) in each $0.4 \mathrm{~m}$ incremental depth down was determined gravimetrically.

It was then converted to water depth ( $\mathrm{mm}$ ) by multiplying by the specific bulk density values measured by the core sampler methods as described by Blake (1965).

Volumetric water content can be calculated from gravimetric water using the following equation:

$$
S M C=\frac{W w-W d}{W d} * 100
$$

Where,

$\mathrm{SMC}=$ Soil moisture content dry base (\%)

$\mathrm{Ww}=$ Weight of the wet soil (g)

$\mathrm{W}_{\mathrm{d}}=$ Weight of the dry soil $(\mathrm{g})$

Volumetric soil water content $\left(\mathrm{cm}^{3} / \mathrm{cm}^{3}\right)$ is determined as:

$$
\theta=w^{*} \rho d
$$

Where,

$\mathrm{w}$ = gravimetric water content

$\rho d=$ bulk density $\left(\mathrm{g} / \mathrm{cm}^{3}\right)$ 


\section{Agronomic data parameters}

Agronomic parameters including grain yield, above ground biomass, plant height and cob length data were collected .To measure cob length and plant height six stands from each plot were randomly selected and measured. Above ground biomass was weighted from each plot at the end of the growing season; the plants were cut, tied in bundles and left to dry for 10 days under the sun. To get grain yield in each plot at the end of the growing season; the heads were cut and the grains were threshed and weighed and yield per plot was recorded.

\section{Results and Discussion}

\section{Effect of treatments on volumetric soil-moisture content}

Table 1. Treatments means for SMC (\%) of the root zone during just after one day RF and after 10 days of rainfall.

\begin{tabular}{|c|c|c|c|c|c|c|}
\hline \multirow[t]{2}{*}{ Treatment } & \multicolumn{2}{|c|}{$\begin{array}{l}\text { Initial period } \\
\text { SMC (\%) }\end{array}$} & \multicolumn{2}{|c|}{$\begin{array}{l}\text { Development period } \\
\text { SMC (\%) }\end{array}$} & \multicolumn{2}{|c|}{$\begin{array}{l}\text { Mid period } \\
\text { SMC (\%) }\end{array}$} \\
\hline & $\begin{array}{c}\text { Just after } \\
\text { one day of } \\
\text { RF }\end{array}$ & $\begin{array}{c}\text { After } 10 \text { days } \\
\text { of rainfall }\end{array}$ & $\begin{array}{c}\text { Just after } \\
\text { one days of } \\
\text { RF }\end{array}$ & $\begin{array}{l}\text { After } 10 \\
\text { days of } \\
\text { rainfall }\end{array}$ & $\begin{array}{c}\text { Just after } \\
\text { one day of } \\
\text { RF }\end{array}$ & $\begin{array}{l}\text { After } 10 \\
\text { days of } \\
\text { rainfall }\end{array}$ \\
\hline Targa & $54.09 a$ & $51.15 a$ & $58.90 a$ & $55.80 a$ & 54.ooa & $46.50 a$ \\
\hline Tie ridge & $45 \cdot 50 a$ & 43.00ab & $54.20 a$ & $52.00 a$ & $50.00 a$ & $42.60 a b$ \\
\hline Zai & $42.32 a$ & $35.60 a b$ & $51.15 \mathrm{a}$ & $23.20 b$ & $48.00 a$ & 31.93ab \\
\hline Control & $40.80 a$ & $35.18 b$ & $44.00 a$ & $26.30 b$ & $45.00 a$ & $30.50 b$ \\
\hline CV (\%) & 16 & 16 & 19 & 16 & 19 & 18 \\
\hline LSD (0.05) & 14 & 8 & 30 & 8 & 12 & 9 \\
\hline
\end{tabular}

Table 2. Comparing each structure for soil moisture content and maize water requirement in growth stages.

\begin{tabular}{|c|c|c|c|c|c|c|c|c|c|}
\hline Treatment & \multicolumn{4}{|c|}{ After one day of RF } & \multicolumn{5}{|c|}{ After 10 days of RF } \\
\hline 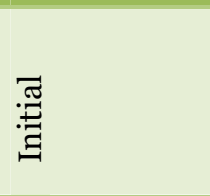 & 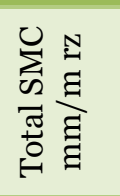 & 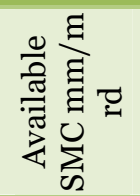 & 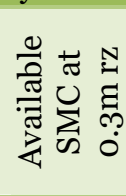 & $\begin{array}{l}\frac{\vec{d}}{0} \\
\stackrel{0}{0}\end{array}$ & 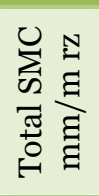 & 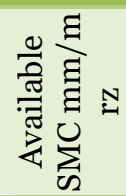 & 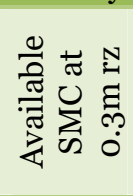 & 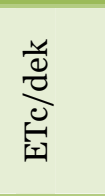 & $\begin{array}{c}\% \text { of crop } \\
\text { water need } \\
\text { satisfaction } \\
\text { at dry spell } \\
\text { period }\end{array}$ \\
\hline Targa & 54.10 & 29.80 & 8.92 & 1.04 & 51.20 & 28.13 & 8.43 & 10.40 & 87 \\
\hline Tie-ridge & 45.50 & 25.00 & 7.50 & 1.04 & 43.00 & 23.65 & 7.00 & 10.40 & 72 \\
\hline Zai & 42.30 & 23.20 & 6.90 & 1.04 & 35.60 & 19.50 & 5.87 & 10.40 & 56 \\
\hline Control & 40.80 & 22.40 & 6.70 & 1.04 & 35.20 & 19.30 & 5.80 & 10.40 & 55 \\
\hline Development & & & $0.86 \mathrm{~m}$ & & & & $0.86 \mathrm{~m}$ & & \\
\hline Targa & 58.90 & 32.30 & 27.70 & 2.63 & 55.80 & 30.70 & 26.30 & 26.30 & 100 \\
\hline Tie ridge & 54.20 & 29.80 & 25.60 & 2.63 & 52.00 & 28.60 & 24.50 & 26.30 & 93 \\
\hline Zai & 51.20 & 28.20 & 24.10 & 2.63 & 23.20 & 12.76 & 11.00 & 26.30 & 42 \\
\hline Control & 44.00 & 24.20 & 20.80 & 2.63 & 26.30 & 14.46 & 12.40 & 26.30 & 47 \\
\hline Mid stage & & & $1 \mathrm{~m}$ & & & & $1 \mathrm{~m}$ & & \\
\hline Targa & 54.20 & 29.80 & 29.80 & 3.00 & 46.50 & 25.60 & 25.60 & 30.00 & 85 \\
\hline Tie ridge & 50.15 & 27.58 & 27.58 & 3.00 & 42.60 & 23.40 & 23.40 & 30.00 & 78 \\
\hline Zai & 48.00 & 26.40 & 26.40 & 3.00 & 31.90 & 17.50 & 17.50 & 30.00 & 58 \\
\hline Control & 45.00 & 24.75 & 24.75 & 3.00 & 30.50 & 16.70 & 16.70 & 30.00 & 55 \\
\hline
\end{tabular}

NB: TAW (total available water), RAW (readily available water), SMC (soil moisture content), rz (root zone) $R A W=T A W^{*} P$; Where, $p$ is critical depletion ( $p=0.5$ for maize). 
The effects of the treatments on soil moisture content (SMC) just after one day of rainfall and after 10 days of rainfall at different growing season were shown in Table 1 and 2. The results obtained showed non-significant differences in SMC between all treatments $(p>0.05)$ at initial period just after one day of rainfall.

There was significant difference between treatments Targa and Control $(\mathrm{p}<0.05)$ after 10 days of rainfall at initial period but no significant difference ( $p>0.05)$ between Tie ridge, Control and Zai shown in Table 1. In Table 2, treatments Targa $(82 \%)$, Tie ridge $(72 \%)$, Zai $(56 \%)$ and Control (55\%) satisfy crop water requirement during dry spell periods (after 10 days of rain rainfall). Similarly, there was no significant differences between treatments (p>0.05) at development period just after one day of rainfall. In Table 2, percent of crop water need satisfaction after 10 days of rainfall was 100\%, 93\%, 42\% and $47 \%$ for Targa, Tie ridge, Zai and Control, respectively. These results showed that the treatment Zai and Control were not satisfying crop water requirements during dry spell period when more water lost from these structures. The result also showed the superiority of the tested techniques (Targa and Tie ridges) over the Control method by reducing run off and evaporation loss. This result was in agreement with McHugh et al. (2007).

Although there was no significant differences between the tested techniques at mid period during just after one day of rainfall on SMC can be put in a descending order as Targa $>$ Tie ridge $>$ Zai $>$ Control. But, significant differences was observed between Targa and Control $(\mathrm{p}<0.05)$ during mid period after 10 days of rainfall and no significant difference $(\mathrm{P}>0.05)$ between Tie ridge, Zai and Control in Table 1 shown. In Table 2, after 10 days of rainfall at mid period treatment Targa, Tie ridge, Zai and Control satisfied 85\%, $78 \%$, $58 \%$ and $55 \%$ crop water requirement during dry spell periods, respectively. The results obtained showed at all the growing season significant difference in SMC $(\mathrm{P}<0.05)$ between in-situ water harvesting structures and control on 10 days after rainfall (at dry season).

Next to Targa higher soil moisture content stored on Tie ridge structure. The present findings was agreed with (Botha, 2006) who stated that RWH techniques reduce unproductive water losses, particularly evaporation (E) and run off (R) and optimize rainwater productivity. The results indicated that the efficiency of Targa in retaining water was better, because the ridges were made up of maize residue and soil are able to improve soil water content in the soil root zone during cropping period compared with control. According to studies from Northern Ethiopia on in-situ water harvesting systems, tied-ridging, open ridging and sub-soiling improved soil water content at the root zone during cropping period compared to the Traditional tillage by $24 \%, 15 \%$ and $3 \%$, respectively (McHugh et al., 2007).

\section{Effect of water conservation methods on growth of maize}

Table 3. Mean growth parameters of maize under moisture conservation structures.

\begin{tabular}{|c|c|c|c|c|}
\hline Treatment & $\mathrm{GY}\left(\right.$ tha $\left.^{-1}\right)$ & DMB (tha $\left.{ }^{-1}\right)$ & $\mathrm{Ph}(\mathrm{cm})$ & $\mathrm{CL}(\mathrm{cm})$ \\
\hline Targa & $7.15 a$ & $8.23 a$ & $208 a$ & $39.36 a$ \\
\hline Tie ridge & $6.19 a$ & 7.8ab & $202 a$ & $35.26 \mathrm{~b}$ \\
\hline Zai & $4.50 \mathrm{ob}$ & $5.76 c$ & 201a & $37 \cdot 30 a b$ \\
\hline Control & $4.90 \mathrm{~b}$ & $6.15 \mathrm{bc}$ & $196 a$ & $35.50 b$ \\
\hline $\mathrm{CV} \%$ & 9.40 & 13.00 & 3.90 & 2.96 \\
\hline LSD (0.05) & 1.00 & 1.90 & 15.80 & 2.18 \\
\hline
\end{tabular}

NB: GY (grain yield), DMB (dry matter biomass), Ph (plant height), CL (cob length). Treatments with the same letters have no significant difference.

\section{Plant Parameters}

\section{Grain yield}

As shown in Table 3 above and Fig. 3 below, the grain yield of maize was increased significantly $(\mathrm{p}<0.05)$ in targa $\left(7.15 \mathrm{t} \mathrm{ha}^{-1}\right)$ followed by Tie ridge $\left(6.19 \mathrm{t} \mathrm{ha}^{-1}\right)$, and there was no significant difference ( $p>0.05)$ between Zai $\left(4.50 \mathrm{t} \mathrm{ha}^{-1}\right)$ and Control (4.90 $\mathrm{t} \mathrm{ha} \mathrm{h}^{-1}$ ) treatment. However, the treatment Targa $\left(7.15 \mathrm{t} \mathrm{ha}^{-1}\right)$ and Tie-ridge $(6.19 \mathrm{t}$ $\left.\mathrm{ha}^{-1}\right)$ has significant $(\mathrm{P}<0.05)$ differences in grain yield than the Control (4.90 $\left.\mathrm{t} \mathrm{ha}^{-1}\right)$. According to Agriculture and Natural Resource office of Humbo woreda (study area), the average grain yield production of maize in the area on irrigated and without irrigation was reported to be $3.67 \mathrm{t}$ $\mathrm{ha}^{-1}$ and $2.25 \mathrm{t} \mathrm{ha}^{-1}$, respectively. Which indicates that, practicing of in-situ moisture conservation structures particularly Targa can produce more crop yield than Control. Control treatment in the present study showed the lower yield compared with Targa and Tie ridge, Control treatments may attributed to the low ability to retain the soil moisture as in Table 3 and 4 above shown. This result is also in conformity with the findings of Solomon (2015) and Yoseph (2014) who reported that maize grain yield was significantly affected by moisture conservation practices. When soil available water content decrease, the number of grain per plant and yield per unit area declines (Mansouri and Saberali, 2010). Through RWH (rainwater harvesting) structures determining the production increases through the efficiency of the techniques in conserving rainwater when compared with control. The current results agree 
with the findings of Botha, (2006) who reported that RWH was found to be the most appropriate measure of determining the efficiency of the techniques to improve dry land crop yields. Similarly, Barron and Okwach (2005) showed that, rainwater harvesting technique increased yield by about $70 \%$ in semi-arid Kenya.

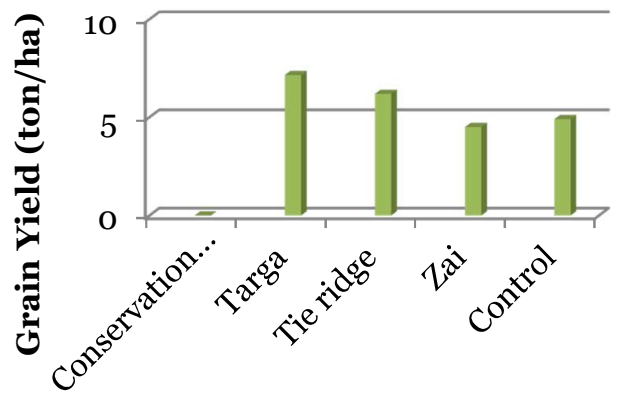

Fig. 3. Effect of treatments on grain yield.

\section{Dry matter biomass}

Biomass yields for different treatments were summarized in Table 3 and Fig. 4. There was significant difference $(\mathrm{P}<0.05)$ between all treatments on the maize dry matter biomass. There was significant different $(\mathrm{p}<0.05)$ between Targa, Zai and Control, however, Targa do not differ significantly from Tie ridge and Tie ridge do not significantly different $(p>0.05)$ between control and significant difference $(\mathrm{p}<0.05)$ between Zai and Tie ridge treatments. Values can be arranged in descending order as Targa, Tieridge, Control, and Zai. The treatments Targa and Tie ridge had the highest biomass production of $8.23 \mathrm{tha}^{-1}$ and $7.80 \mathrm{t} \mathrm{ha}^{-1}$ biomass yield for the maize growing seasons, respectively than the treatment Control (6.15 t ha-1) and Zai (5.76 t ha1). The lower biomass production was obtained under treatment $\mathrm{Zai}$ and control due to in efficiency to conserve moisture during dry spell periods as shown in Table 3 .

\section{Biomass}

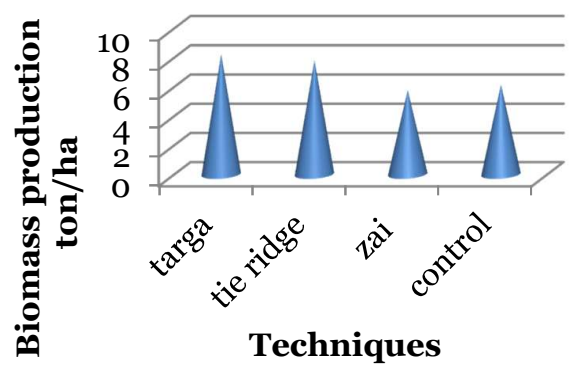

Fig. 4. Effects of treatments on dry matter biomass production.

\section{Plant height}

As can be seen from the Table 4 and Fig. 5 there was no significant ( $p>0.05)$ difference between among all the treatments in plant height during the maize growing season. However, water harvesting technique was superior in plant height, the values of the tested techniques can be put in a descending order as Targa, Tie-ridge, Zai and Control in the maize growing season. The results showed that the water harvesting increased the plant height because it led to increase the rate of leakage of water into the soil and which led to increased soil moisture content as shown in Table 3. The results agreed with the findings of Ahmed et al., (2018) who reported that in-situ water harvesting techniques increased the yields of maize and accompanied with increase of plant height.

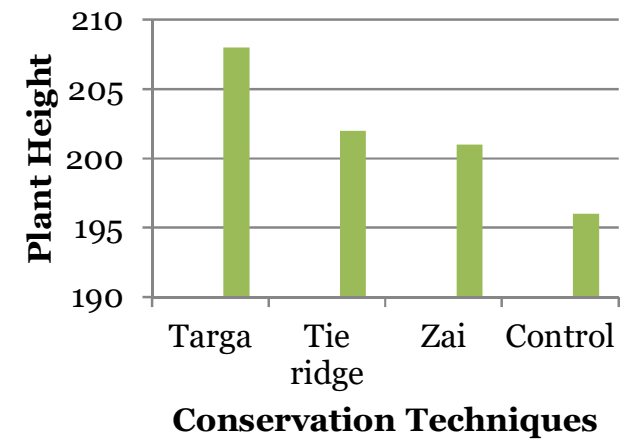

Fig. 5. Effects of treatments on plant height.

\section{Cob length}

As shown in above Table 3 and Fig. 6 there was significant $\quad(\mathrm{p}<0.05) \quad$ difference between treatments Targa, Zai, Tie-ridge and Control. There is no significant ( $>>0.05)$ difference between Tie ridge, Zai and Control. The result showed that cob length of maize increased by Targa treatments compared to Control. This was also in conformity with the findings of Solomon (2015) and Yoseph (2014) who reported that maize grain yield and yield components were affected significantly by moisture conservation practices.

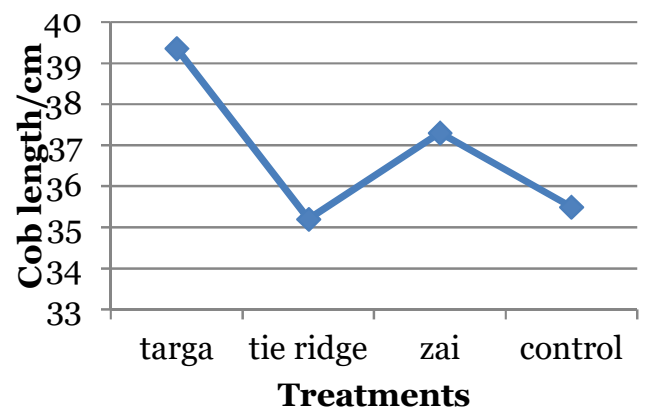

Fig. 6. The effects of treatments on cob length. 


\section{Gross returns}

As shown in Table 4 below, among the different rainwater harvesting techniques, Targa recorded highest gross returns (45045 ETB ha') compared to other conservation methods. The next best was conservation measures Tie ridge by recording higher gross returns (38997 ETB ha-1) than
Control. Control recorded gross returns (30870 ETB ha-1) and Zai water conservation measures recorded lowest gross return (28350 ETB ha-1) compared to all other treatments.

\section{Economic costs and benefit analysis of treatments}

Table 4. Estimated economic costs per hectare of treatments.

\begin{tabular}{|c|c|c|c|c|c|c|c|c|c|c|c|}
\hline Treatments & $\begin{array}{c}\text { Average } \\
\text { yield } \\
\left(\mathrm{t} \mathrm{ha}^{-1}\right)\end{array}$ & $\begin{array}{l}\text { Adjusted } \\
\text { yield } \\
\left(\mathrm{t} \mathrm{ha}^{-1}\right)\end{array}$ & $\begin{array}{l}\text { Unit } \\
\text { price } \\
\text { ETB kg-1 }\end{array}$ & $\begin{array}{l}\text { Gross } \\
\text { field } \\
\text { benefit } \\
\text { (ha) }\end{array}$ & $\begin{array}{l}\text { Cost of } \\
\text { labor }\end{array}$ & $\begin{array}{c}\text { Cost of } \\
\text { agro- } \\
\text { chemicals }\end{array}$ & $\begin{array}{c}\text { Cost of } \\
\text { maize } \\
\text { seed }\end{array}$ & $\begin{array}{l}\text { Cost of } \\
\text { fertilizer }\end{array}$ & $\begin{array}{l}\text { Total } \\
\text { costs } \\
\text { that vary } \\
\text { (ha) }\end{array}$ & $\begin{array}{c}\text { Net } \\
\text { benefits } \\
\text { ha }^{-1}\end{array}$ & $\begin{array}{l}\text { Benefit } \\
\text { cost } \\
\text { ratio }\end{array}$ \\
\hline Targa & 7.15 & 6.435 & 7 & 45045 & 8833 & 1000 & 500 & 5000 & 15333 & 29712 & 1.93 \\
\hline Tie-ridge & 6.19 & 5.571 & 7 & 38997 & 7333 & 1000 & 500 & 5000 & 13833 & 25164 & 1.81 \\
\hline Zai & 4.50 & 4.050 & 7 & 28350 & 7500 & 1000 & 500 & 5000 & 14000 & 14350 & 1.02 \\
\hline Control & 4.90 & 4.410 & 7 & 30870 & 5500 & 1000 & 500 & 5000 & 12000 & 20370 & 1.69 \\
\hline
\end{tabular}

\section{NB: ETB: Ethopian Birr}

\section{Net returns}

Table 4 shows the expenditure on materials and operations incurred by farmers for production of maize. Net revenue computed as total revenue minus total variable costs was presented in Table 4. As in above Table shown among the different rainwater harvesting techniques, Targa and Tie ridge recorded higher net returns (29712 $\mathrm{ETB} \mathrm{ha}^{-1}$ and $25164 \mathrm{ETB} \mathrm{ha}^{-1}$ ) than Control (20370 ETB ha1) and Zai (14350 ETB ha-1). It means rainwater harvesting system with Targa and Tie ridge has direct effects on crop production and economic benefits over control due to better moisture holding capacity.

An average of 29712 ETB constituting 193\% of the total revenue was earned as net revenue per hectare in Targa techniques. An average of 25164 ETB constituting $181 \%$ of the total revenue was earned as net revenue per hectare in Tie ridge techniques. An average of 20370 ETB, constituting $169 \%$ of the total revenue was earned as net revenue per hectare in conventional. This result indicated that Targa in-situ rainwater harvesting techniques by $24 \%$ of the total revenue was earned as net revenue per hectare and Tie ridge in-situ rainwater harvesting techniques by $12 \%$ of the total revenue was earned as net revenue per hectare increased over conventional. Which was consistent with findings from the study conducted by Vohland and Barry (2009) rainwater-harvesting systems and the adoption of the rainwater harvesting practices have positive effect on incomes, measured in return to labour. In the case of soil and water conservation measures (in-situ rainwater harvesting structures), it usually involves significant initial and on-going investment in both cash and labour with benefits being realized in the long term (Ellis-Jones and Tengberg, 2000).

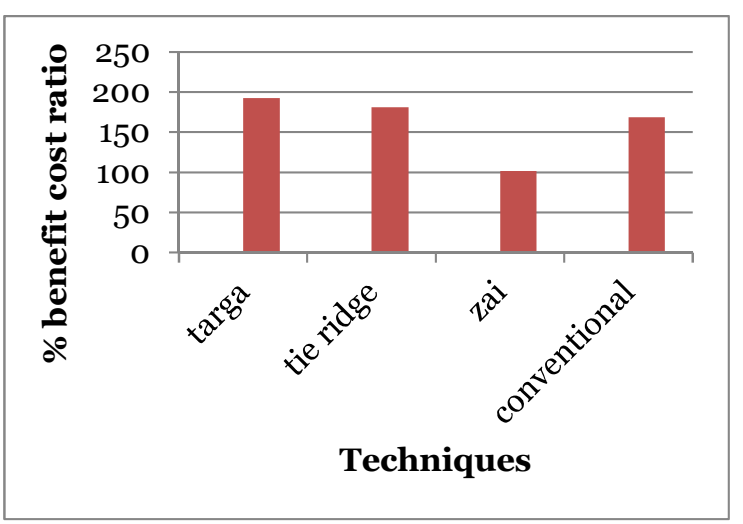

Fig. 7. Percent of the treatments benefit cost ratio.

\section{Conclusion}

The characteristics of agriculture in Humbworeda is predominantly rain-fed farming. This farming system resulted in fluctuating food crop productivity mainly due to moisture stress during mid and developmental season emanated from rainfall variability in the This study was conducted to know the potential of in-situ water harvesting techniques on maize yield, yield components and soil moisture. The comparative study between the Control, Zai, Targa and Tieridge showed that the soil moisture, grain yield and biomass for the Targa were consistently higher when compared to the control. Accordingly, out of IRWH technologies Targa is observed to be a climate smart technique, which contributes to conservation of natural resources (conserve soil moisture and reduces surface runoff water) and increase yield at dry land condition. These water harvesting structures on farmers' fields have minimum cost, less labor power required, do not leave much space as well as simple to construct. This study clearly demonstrated that in-situ rainwater harvesting 
techniques could play an important role in improving soil water storage, crop yields and extending the growing seasons in dry periods. The implementation and adoption of these techniques will however require careful planning, community participation and to better understanding of the choices in making decision.

\section{References}

Abiye, A., Jabbar, M., Mohamed Saleem, M.A. and Erkossa, T. 2002. Development and testing of low cost animal drawn minimum tillage implements: Experience on Vertisols in Ethiopia. Agril. Mecha. Asia, Africa and Latin America. 33: 9-14.

Ahmed M. El Naim, Sabah M. Hamoda, Elshiekh A. Ibrahim, Moayad M. B. Zaied and Elsadig B. Ibrahim. 2018. Performance of in-situ rain water harvesting on yield of grain sorghum in gradud soil of north Kordofan. Int. J. Agric. Forest. 8(2): 77-82.

https://doi.org/10.5923/j.ijaf.20180802.05

Ahmed, A.A. and Naggar, O.M. 2003. Rain Water Harvesting Concept and Techniques. Water Harvesting for Food Security and Sustainable Development. UNESCO Chair in Water Resources, Conference in Water Harvesting and the Future of Development in Sudan, Khartoum, Aug 2003. pp. 19-20.

Araya, A. and Stroosnijder, L. 2010. Effects of tied-ridges and mulch on barley (Hordeum vulgare) rainwater use efficiency and production in Northern Ethiopia. Agril. Water Manage. 97(6): 841-847. https://doi.org/10.1016/j.agwat.2010.01.012

Awulachew, S.B., Merry, D.J., Kamara, A.B., Van Koppen, B., Penning De Vries, F., Boelee, E., Makombe, G., 2005. Experiences and opportunities for promoting small-scale micro irrigation and rainwater harvesting for food security in Ethiopia. IWMI, Colombo, Sri Lanka, (Working paper 98). p.86.

Barron, J. and Okwach, G. 2005. Run-off water harvesting for dry spell mitigation in maize (Zea mays L.): Results from on-farm research in semi-arid Kenya. Agril. Water Manage. 74: 1-21.

https://doi.org/10.1016/j.agwat.2004.11.002

Biazin, B., Sterk, G., Temesgen, M., Abdulkedir, A. and Stroosnijder, L. 2012. Rainwater harvesting and management in rain fed agricultural systems in sub-Saharan AfricaA review. Phys. Chem. Earth. 47-48: 139151. https://doi.org/10.1016/j.pce.2011.08.015

Blake, G.R. 1965. Bulk Density in Methods of Soil Analysis. Agronomy, No. 9, Part 1, C.A. Black. pp. 374-390.

https://doi.org/10.2134/agronmonogr9.1.c30

Botha, J.J. 2006. Evaluation of maize and sunflower production in a semi-arid area Infield rainwater harvesting. PhD Thesis,
University of Free State, Bloemfontein, South Africa. 353p.

Debelle, T. and Friessen, D. 2001. Effect of enriching farmyard manure with mineral fertilizer on grain yield of maize at Bako, western Ethiopia. Seventh Eastern and Southern African Maize conference 11-15 February. pp. 335-337.

Ellis-Jones, J. and Tengberg, A. 200o. The impact of indigenous soil and water conservation practices on soil productivity: Examples from Kenya, Tanzania and Uganda. Land Degrad. Dev. 11: 19-36.

https://doi.org/10.1002/(SICI)109914.5X(200001/02)11:1<19::AID-LDR $357>3.0 . C O ; 2-2$

FAO. 2005. Drought resistant soils; Optimization of soil moisture for sustainable plant production. Food and Agricultural organization, Rome, Italy. 82p.

Fitsum, H., Pender, J. and Gebresilassie, N. 1999. Land degradation in the highlands of Tigray, and strategies for sustainable land management. Socio-economic and policy research working paper no. 25. International Livestock Research Institute, Addis Ababa, Ethiopia. 75p.

Gardner, W.H. 1986. Water Content. In: Methods of Soil Analysis, Part 1. Physical and Mineralogical Methods- Agronomy Monograph No 9 (2 $^{\text {nd }}$ Edition) American Society of Agronomy, Soil Science Society of America, Madison. 1402p.

Mahoo, H.F., Mkoga, Z.J., Kasele, S.S., Igbadun, H.E., Hatibu, N., Rao, K.P.C. and Lankaford, B. 2007. Productivity of water in agricultureFarmers' perceptions and practices. Colombo, Sri Lanka: International Water Management Institute (Comprehensive Assessment of Water Management in Agriculture), CA Discussion paper 5. ISBN 978-92-9090-679-7. 31p.

Mansouri, C. and Saberali, F. 2010. Maize yield response to deficit irrigation during lowsensitive growth stages and nitrogen rate under semi-arid climatic conditions. Agril. Water Manage. 97(1): 12-22.

https://doi.org/10.1016/j.agwat.2009.08.003

McHugh, O.V., Steenhuis, T.S., Abebe, B. and Fernandes, E.C.M. 2007. Performance of Insitu rainwater conservation tillage techniques on dry spell mitigation and erosion control in the drought-prone North Wello zone of the Ethiopian highlands. Soil Tillage Res. 97(1): 19-36.

https://doi.org/10.1016/j.still.2007.08.002

Mintesinot, B. and Mitiku, H. 2002. Water harvesting in northern Ethiopia: environmental, health and socio-economic impacts. In: P.G., McCornick, A.B, Karma, G., Tadesse (eds.). Integrated water and land management research and capacity building priorities for Ethiopia. In: Proceedings, 
MoWR/EARO/IWMI/ILRI, International Workshop; 2-4 December, ILRI, Addis Ababa, Ethiopia. pp. 185-191.

MLARR. 2001. The Agricultural Sector of Zimbabwe: Statistical Bulletin-2001, Ministry of Lands Agriculture and Rural Resettlement, Harare. 6op.

Ngigi, S.N., Savenije, H.H.G., Thome, J.N., Rockström, J., Penning de Vries, F.W.T. 2005. Agro-hydrological evaluation of onfarm rainwater storage systems for supplemental irrigation in Laikipia district, Kenya. Agril. Water Manage. 73(1): 21-41. https://doi.org/10.1016/j.agwat.2004.09.021

Rockström, J., Barron, J. and Fox, P.2002. Rainwater management for increased productivity among small-holder farmers in drought prone environments. Phys. Chem. Earth. 27(11-22): 949-959.

https://doi.org/10.1016/S1474-7065(02)00098-0

SAS Institute. 2007. SAS User's Guide in Statistics. $9^{\text {th }}$ Edition, SAS Institute, Inc., Cary. pp. 337-340.

Solomon, T. 2015. On-farm verification of the effects of selected soil moisture conservation techniques on yield and yield components of early maturing maize varieties at Bako, western Ethiopia. Int. J. Adv. Earth Sci. Eng. 4(1): 254-264.

Vohland, K. and Barry, B. 2009. A review of Insitu rainwater harvesting (RWH) practices modifying landscape functions in African dry lands. Agric. Ecosyst. Environ. 131: 119-127. https://doi.org/10.1016/j.agee.2009.01.010

WZFED (Wolaita Zone Finance and Economy Development). 2007. Yearly Report on Wolaita Zone and Rural Woredas' Economy. Wolayta Sodo, Ethiopia. pp. 119-122.

Yosef, B.A. and Asmamaw, D.K. 2015. Rainwater harvesting: An option for dry land agriculture in arid and semi-arid Ethiopia. Int. J. Water Res. Environ. Eng. 7: 17-28. https://doi.org/10.5897/IJWREE2014.0539

Yoseph, T. 2014. Evaluation of moisture conservation practices, inter and intra row spacing on yield and yield components of pearl millet (Pennisetum glaucum) at Alduba Southern Ethiopia. J. Nat. Sci. Res. 4(9): 7985 . 